\title{
Electrical Stimulation Induced Cervical Medial Branch Referral Patterns
}

\author{
Robert E. Windsor, MD, Diwakar Nagula, DO, Seneca Storm, MD, Anthony Overton, DO, and Scott Jahnke, DO
}

Study Design: Electrical stimulation of the right cervical medial branches with or without the third occipital nerves was performed in nine subjects for a total of forty-eight medial branches and eight third occipital nerves. The referral patterns of each nerve or nerve branch was mapped on a human line diagram. These diagrams were compared to facet joint (zygapophyseal joint, facet joint), myofascial, and discogenic referral patterns already published by various authors.

Objective: To determine the referral patterns of the cervical medial branches and the third occipital nerve.
Hypothesis: The cervical medial branch referral patterns created by electrical stimulation may differ from those reported from other etiologies and may prove to be useful when considering various cervical pain syndromes.

Methods: The third occipital nerve and third through eighth medial branches of the cervical posterior rami of nine subjects with and without a history of neck pain were electrically stimulated under fluoroscopic imaging. All subjects were blinded to the level of stimulation, and the referral patterns of each individual were mapped out on a human line drawing by the primary author of this study. These referral patterns were compared to referral patterns reported from other etiologies by various authors.

Conclusions: Electrical stimulation of the third occipital nerve as well as the medial branch of the right $\mathrm{C}_{3}-\mathrm{C}_{8}$ posterior primary rami create discrete, reproducible referral patterns which differ from those reported from other etiologies by various authors.

Keywords: Zygapophyseal joint, facet joint, medial branch, referral pattern, myofascial pain, headaches, discogenic
Neck pain is a poorly understood symptom and is often ascribed to "disk disease" or "soft tissue injury" (1). Any structure innervated by the cervical spinal nerves can be a source of neck pain and referred pain to the head, upper limb, or chest wall (2). It is important to correctly identify the appropriate pain generator in order to effectively treat neck pain. Various researchers have published data derived from the stimulation of somatic structures in order to help identify the etiology of pain syndromes when they present clinically. In 1938, Lewis (3) published the results of injecting various noxious substances into muscles, ligaments, and periosteum and found that the pain quality and pattern provoked was more dependent upon the structure injected and less dependent upon the substance injected. Also in 1938, Kellgren (4) published pain patterns derived from the injection of $6 \%$ hypertonic saline into mus-

From Georgia Pain Physicians and Emory University Atlanta, Georgia. Address Correspondence: Robert E. Windsor, MD, Georgia Pain Physicians, 2550 Windy Hill Rd., Suite 215, Marietta, Georgia- 30067 E-mail: rwindsor@aol.com

Funding: There was no external funding in preparation of this manuscript. cles. In 1939, Kellgren and Lewis (5) combined efforts to publish a more detailed work relating to reflex and autonomic changes associated with pain produced from the injection of noxious substances into various tissues. In 1959, Cloward (6) published pain patterns obtained from the stimulation of cervical discs during discography. Facet pain (zygapophyseal, Zjoint, apophyseal joint) pain was first described by Goldwait (7) in 1911. In 1933, Ghormley (8) first coined the phrase "facet syndrome." Subsequently, a number of researchers have implicated the facet joint as a source of back pain (9-72). In 1976, Mooney and Robertson (9) published the referral patterns created by fluoroscopically guided intra-articular lumbar facet joint injections with hypertonic saline in both symptomatic and asymptomatic volunteers. In 1979, these results were confirmed by McCall et al (10). Recently, the facet joint syndrome has been called into question $(12,73)$. It has also been reported that a trained manual therapist can accurately identify the level and side of a painful facet joint (2) although Schwarzer et al (12) have demonstrated that history and physical examination are inaccurate in identifying painful facet joints as iden- tified by diagnostic injections.

Cervical facet joints have been shown by many authors to be a source of neck pain $(1,74-113)$. Carefully performed anesthetic blocks of the medial branches of the cervical posterior primary rami are a specific and sensitive test for the diagnosis of facet joint pain (1). Each cervical facet joint below $\mathrm{C} 2-\mathrm{C} 3$ is supplied with sensation by the medial branch of the posterior rami above and below. The $\mathrm{C} 2-\mathrm{C} 3 \mathrm{fac}-$ et joint differs in that it is supplied by the third occipital nerve and a small, inconstant branch from the greater occipital nerve (77). The $\mathrm{C} 3-\mathrm{C} 8$ medial branches consistently curve around the "waist of the pillar" of the same numbered vertebrae. Many researchers do not feel that the $\mathrm{CO}-\mathrm{C} 1$ and $\mathrm{C} 1-\mathrm{C} 2$ are not true facet joints. While they are diarthrodial joints like facet joints, they differ in that they are located anterior to the facet joint line, are innervated by the $\mathrm{C} 1$ and $\mathrm{C} 2$ anterior ramus respectively, and their spinal nerves exit posterior to the joint, not as at all other levels of the spine.

Diagnostic lumbar intra-articular injections and medial branch blocks have been used to determine the role of these joints in the production of back pain (8- 
$30,32,35-42,49,57,58,61-68,70-74)$. Similarly, diagnostic joint injections and medial branch blocks have been used to identify painful facet joints in the cervical spine (76-78, 81-113). There have been many reported methods of treating painful cervical facet joints. After carefully controlled, positive diagnostic blocks, radiofrequency neurotomy of medial branches may be effective in providing pain relief in those suffering from chronic neck pain of facet joint etiology $(75,103$, 104, 108-113). There have been mixed reports regarding the efficacy of intra-articular corticosteroid injections of the cervical facet joints. Several studies tout the benefits of such injections $(84,87,88)$. However, Barnsley et al (100) reported no benefit of intra-articular injection of corticosteroid following whiplash injury.

Studies published by Dwyer et al (75) and Fukui et al (96) have demonstrated that the distention of asymptomatic and symptomatic cervical facet joints with non-ionic contrast medium may provoke neck pain and referred pain (Fig. 1). Stimulation of the C2-C3 facet joint provokes occipital head pain, stimulation of the C4C5 through C6-C7 provokes shoulder pain, and stimulation of the C7-T1 facet joint provoked interscapular pain (94). Dreyfuss et al $(83,88)$ has demonstrated that provocation of the $\mathrm{CO}-\mathrm{C} 1$ joint provides a variable referral pattern and $\mathrm{C} 1-\mathrm{C} 2$ joint consistently refers pain to the occiput.
The object of this study was to stimulate the cervical medial branches and third occipital nerve to determine if there was a consistent referral pattern that is distinct from the referral pattern arising from the previously published intra-articular stimulation of the cervical facet joints.

\section{Methods}

Nine healthy subjects with and without a history of neck pain and headaches were selected for this study. All nerve studied were on the right side of the neck. Forty-one medial branches and eight third occipital nerves were evaluated. The principal author performed the procedure on all subjects. The subjects were placed prone on a radiolucent fluoroscopy table. The posterior aspect of their neck and shoulder girdles were prepped with isopropyl alcohol and povidone iodine $10 \%$ solution in a sterile manner and draped with sterile towels. For upper cervical stimulation, the head was rotated slightly to the left side to remove the mandible from the relevant fluoroscopic view. The image intensifier was rotated in a slightly caudal manner to make the pillar view more prominent. The waist of the pillar view and lateral border of the $\mathrm{C} 2-\mathrm{C} 3 \mathrm{fac}-$ et joint was identified in all subjects. The skin and subcutaneous tissues was infiltrated with buffered 1\% Lidocaine prior to initiating stimulation. Care was taken to avoid anesthetizing the facet joints or

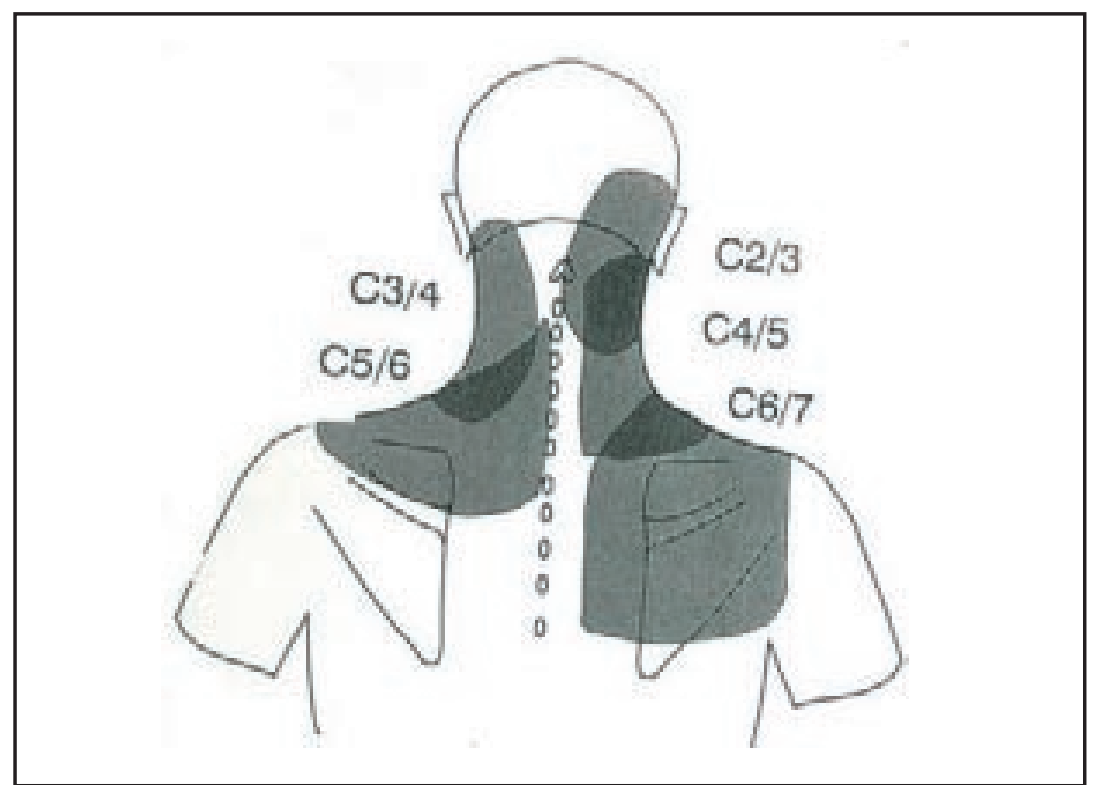

Fig. 1. A map of the characteristic areas of pain referral from cervical facet joints of C2-C3 through C6-C7 (75).

medial branches. A Radionics RFG Plus unit (Radionics, 22 Terry Avenue, Burlington, MA 01803) was utilized for each procedure and subject was appropriately grounded.

Using an "en pointe" approach, with a $22 \mathrm{G} 100.5 \mathrm{~mm}$ SMK probe with an exposed, curved active tip or a $20 \mathrm{G} 145 \mathrm{~mm}$ SMK probe with a $5 \mathrm{~mm}$ curved, active tip was used for the procedure. The active electrode was initially placed down to the waist of the pillar view for stimulation of the C3-C6 medial branches, the junction of the $\mathrm{C} 7$ superior articular process and the $\mathrm{C} 7$ transverse process for stimulation of the $\mathrm{C} 7$ medial branch, and the T1 superior articular process and the $\mathrm{T} 1 \mathrm{rib}$ for stimulation of the $\mathrm{C} 8$ medial branch. For the third occipital nerve, the active tip was initially placed down to the lateral mid point of the C2-C3 facet joint (78). Once the probe was in an adequate radiographic position, the nerve was stimulated at 50 $\mathrm{Hz}$. In each case, the probe was manipulated until the sensory threshold was less than 0.5 volts however; the threshold was usually less than 0.35 volts. In each individual, the third occipital nerve was found either at the mid point of the convexity of the C2-3 facet joint or at the junction of the middle and lower third of the convexity of the $\mathrm{C} 2-\mathrm{C} 3$ facet joint. The $\mathrm{C} 7 \mathrm{me}-$ dial branch was also slightly variable in location. In five individuals it was found and the junction of the $\mathrm{C} 7$ superior articular process and the $\mathrm{C} 7$ transverse process however in the other four individuals it was found further laterally and caudally on the transverse process. During each stimulation, the referral of stimulation was mapped on a human line drawing by the second author with direction from the patient and the first author. At no time was there radicular stimulation. No complications were observed.

\section{RESULTS}

Relatively reproducible referral patterns were identified in each subject and for each medial branch or third occipital nerve stimulated (Table $1 \mathrm{~A}$ and $1 \mathrm{~B}$ ). In all subjects, stimulation of the third occipital nerve caused paresthesia immediately caudal to the nuchal ridge and immediately lateral to the $\mathrm{C} 2-\mathrm{C} 3$ joint. In addition to this region of stimulation, one of the subjects reported a "vibration" throughout the ipsilateral occiput (Fig. 2A). Stimulation of the C3 and $\mathrm{C} 4$ medial branch caused a quar- 
Table 1A. Sketches of medial branch referral patterns of subjects 1-5 on a human line drawing by level.

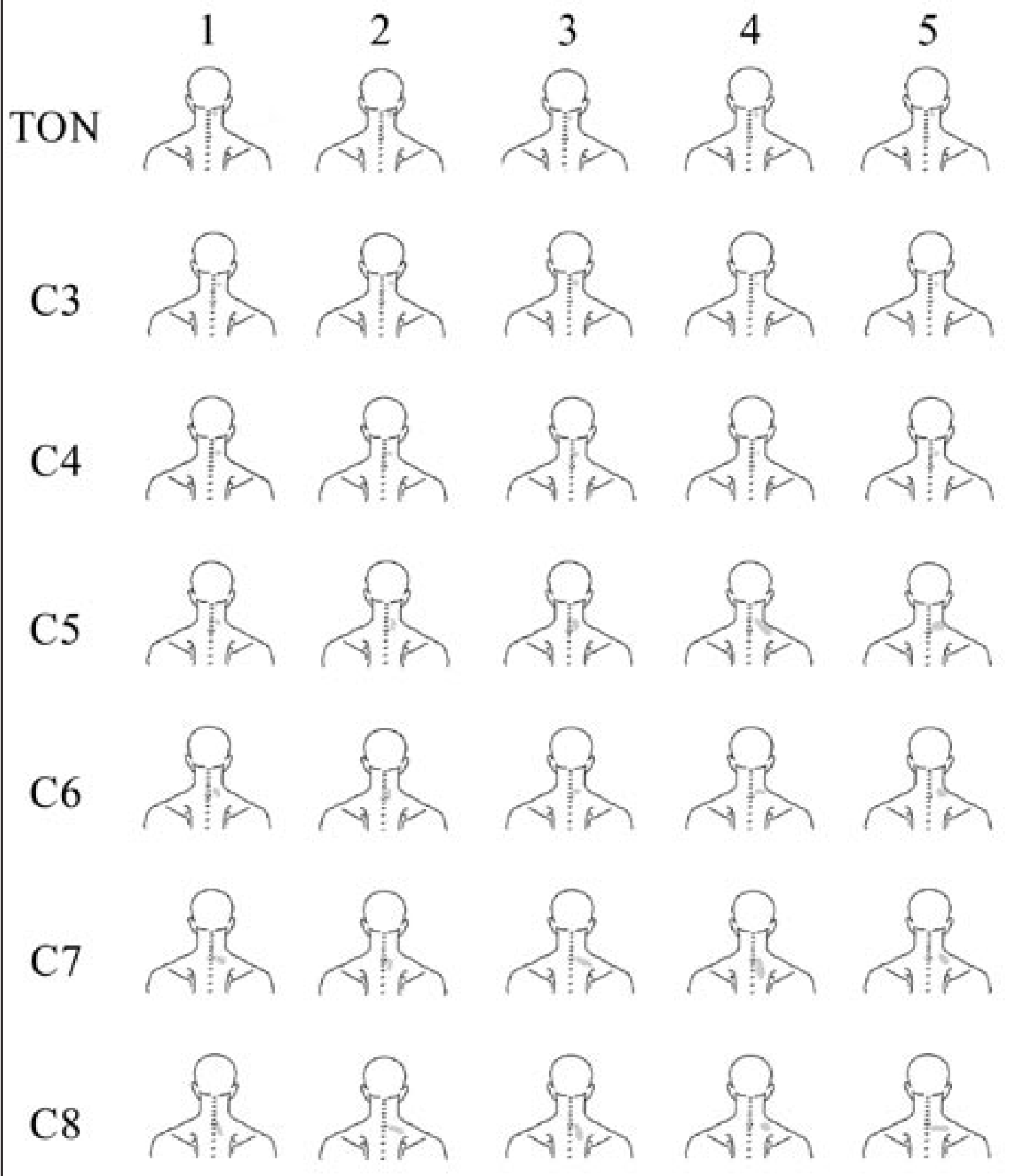


Table 1B. Sketches of medial branch referral patterns of subjects 6-10 on a human line drawing by level.

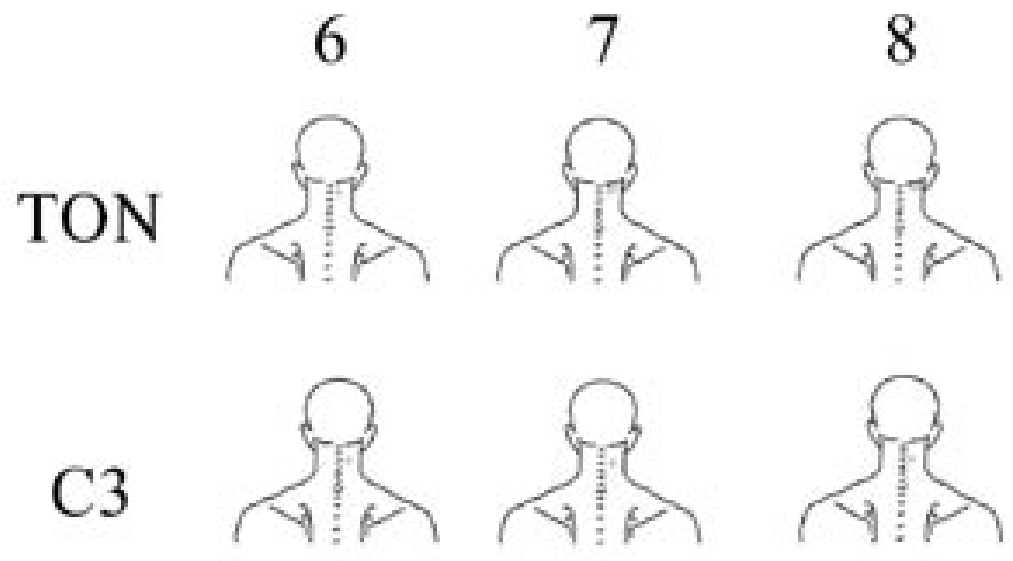

C4
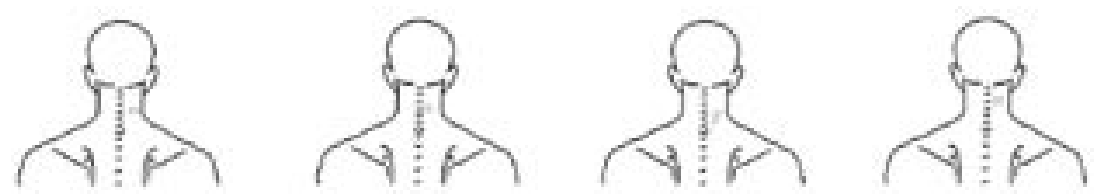

C5
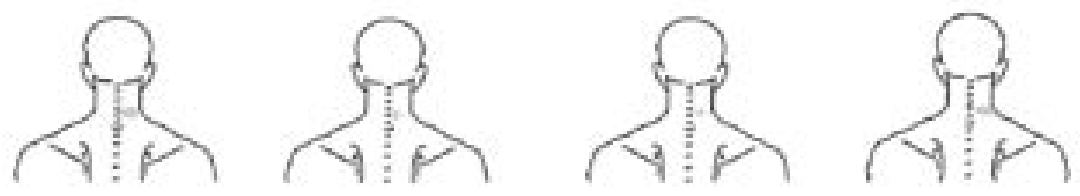

C6
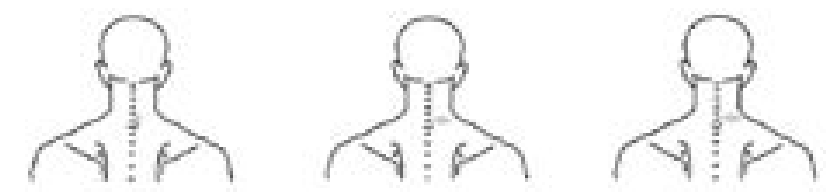

C7
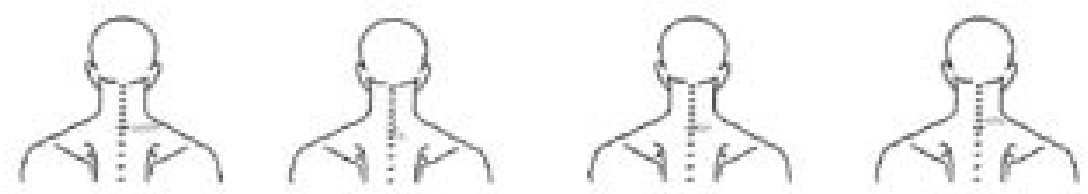

C8
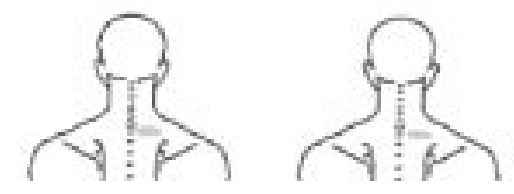


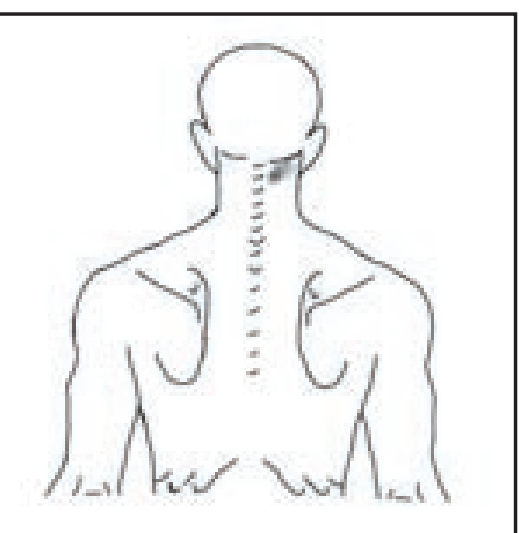

Fig. 2A. A composite drawing of the referral zones of all subjects derived from the minimal threshold stimulation of their right third occipital nerve.

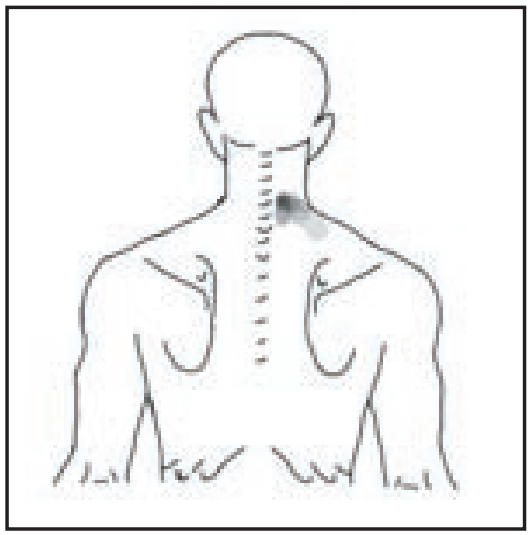

Fig. 2D. Is composite drawing of the referral zones of all subjects derived from the minimal threshold stimulation of their right C5 medial branch.

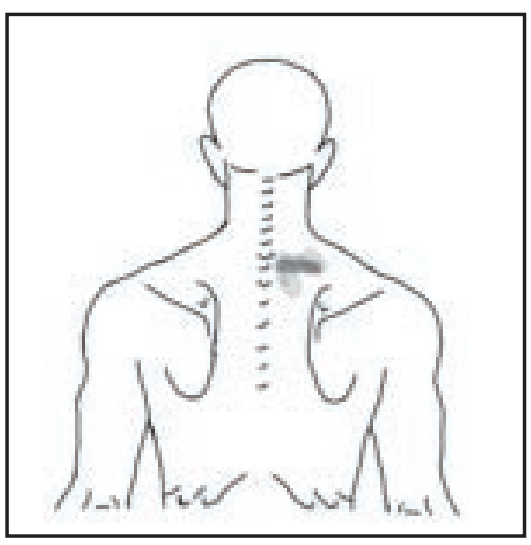

Fig. 2G. A composite drawing of the referral zones of all subjects derived from the minimal threshold stimulation of their right C8 medial branch.

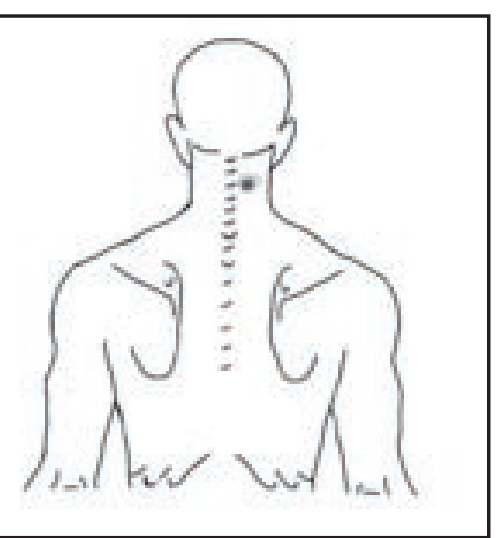

Fig. 2B. A composite drawing of the referral zones of all subjects derived from the minimal threshold stimulation of their right C3 medial branch.

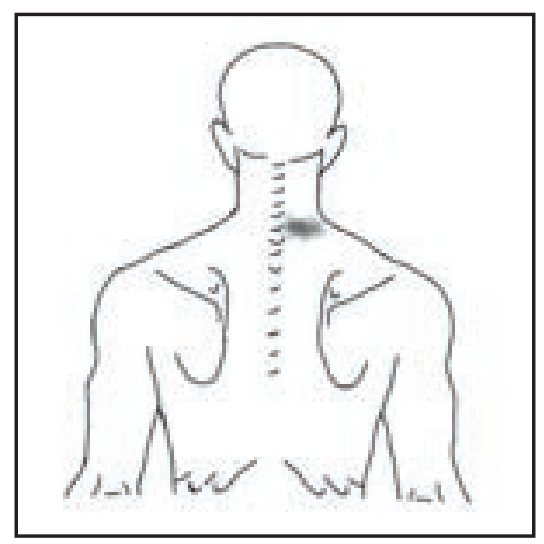

Fig. 2E. Is a composite drawing of the referral zones of all subjects derived from the minimal threshold stimulation of their right C6 medial branch.

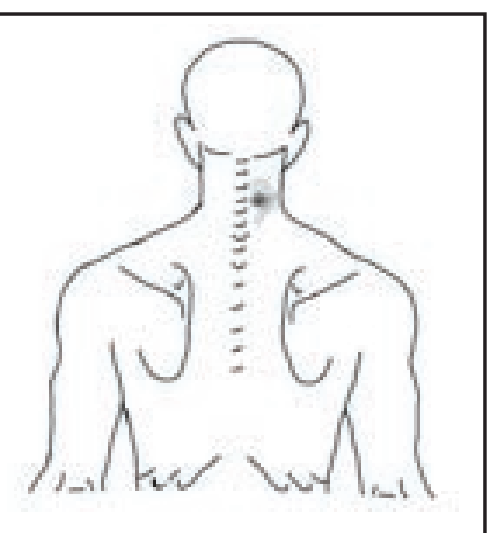

Fig. 2C. A composite drawing of the referral zones of all subjects derived from the minimal threshold stimulation of their right $\mathrm{C} 4$ medial branch.

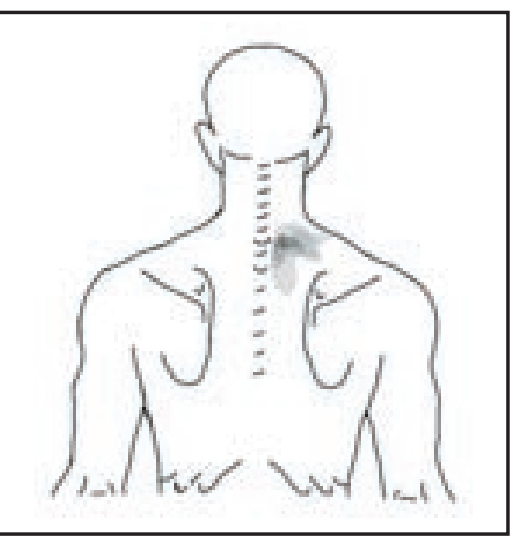

Fig. 2F. A composite drawing of the referral zones of all subjects derived from the minimal threshold stimulation of their right $C 7$ medial branch.

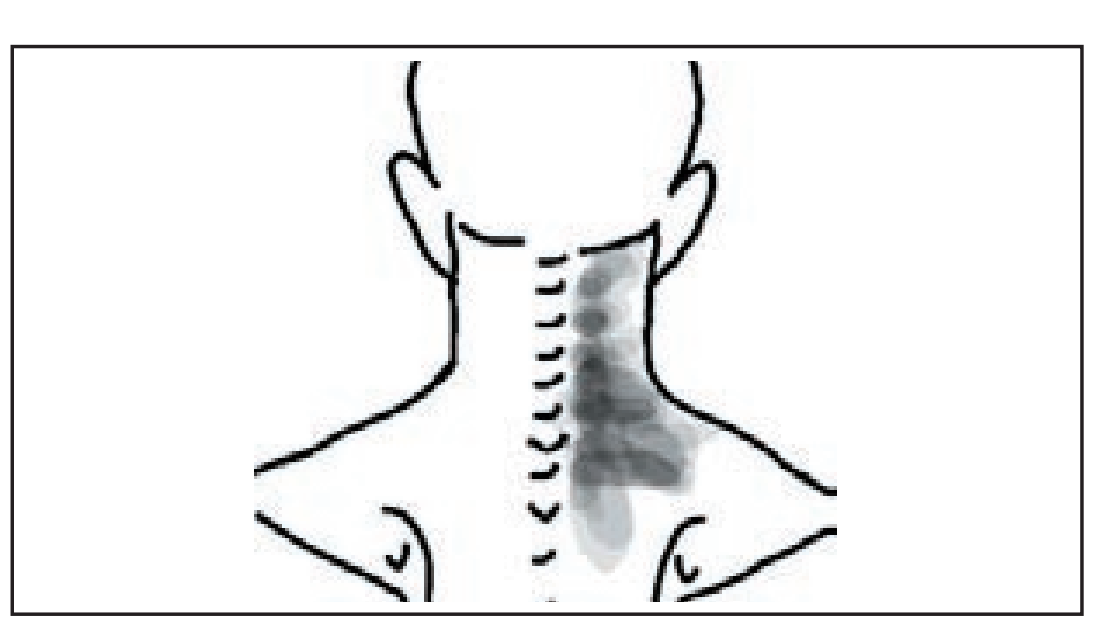

Fig. 3. A composite drawing of the referral patterns of all subjects derived from the minimal threshold stimulation of their right third occipital nerve and C3-C8 medial branches. 
ter sized and shaped paresthesia immediately over or lateral to the C3-4 joint. In addition to this pattern, one individual reported paresthesia radiating caudally from the point of stimulation approximately $5 \mathrm{~cm}$ (Figs. 2B and 2C). Stimulation of the $\mathrm{C} 5$ medial branch caused a 3-4 cm circular or oval region of paresthesia immediately lateral and caudal to the C5-C6 joint. In addition, two subjects reported a $2 \times 5 \mathrm{~cm}$ region of paresthesia extending caudally from the point of maximal stimulus. One other subject also reported a $2 \times 5 \mathrm{~cm}$ oval region of stimulus originating at the point of maximal stimulus and radiating obliquely toward the right shoulder (Fig. 2D). In five subjects, stimulation of the C6 medial branch caused a more or less circular region of stimulus that was $2-4 \mathrm{~cm}$ in diameter approximately $5 \mathrm{~cm}$ lateral to the midline at the C5-6 level and one subject reported a $2 \mathrm{~cm}$ circular region of stimulus immediately lateral to midline at the C5-6 level. In addition, one subject reported a $1 \times 4 \mathrm{~cm}$ oval region of stimulus extending in a caudal direction with the point of maximal tenderness immediately lateral to the C5-6 facet joint and two subjects noted a $2 \times 5 \mathrm{~cm}$ oval region of stimulus extending in horizontally and laterally away from the C5-6 facet joint (Fig. 2E). In stimulating the $\mathrm{C} 7$ medial branch, four subjects noted a circular region of stimulus lateral to the C6-7 facet joint ranging in size from $2-4 \mathrm{~cm}$ in diameter, three subjects noted an obliquely oriented paresthesia pattern directed toward the superomedial angle of the right scapula, one subject noted a vertically oriented paresthesia pattern extending caudally from the C6-7 facet joint in the facetal line, and one subject noted a horizontally and laterally directed paresthesia pattern extending from the C6-7 facet joint (Fig. 2F). In stimulating the C8 medial branch four subjects noted a horizontally arranged paresthesia pattern extending laterally from the C7 level, two subjects noted obliquely oriented paresthesia patterns emanating from the C7 level and extending toward the right interscapular region, and one subject reported a circular $3 \mathrm{~cm}$ region of stimulus approximately $5 \mathrm{~cm}$ lateral to the right C6-7 facet joint (Fig. 2G). In all cases of distally referred stimulation, the point of maximum stimulus was closest to the spine and dissipated the further it went from the spine. If the stimulus was in- creased the size of the stimulation footprint increased (Fig. 3). If the referred stimulation was non-circular and extended from the spine, then a stronger stimulus would cause it to extend further from the spine. In no case did the stimulus extend along a radicular or dermatomal pattern.

\section{DisCussion}

Several researchers have identified various etiologies of referred pain of spinal etiology. This report has demonstrated that the medial branch of the cervical posterior primary rami and the third occipital nerve, when stimulated individually has a separate and distinct referral pattern from the referral patterns previously published. Entrapment of the medial branch has been identified in the lumbar spine $(72,114,115)$ and may occur in the cervical spine. Injury to the medial branch may occur from systemic metabolic conditions such as diabetes (116). Since the cervical facet joint is innervated by the medial branch above and below (77), it seems appropriate that the referral pattern arising from stimulation of the facet joint and each of its medial branches individually would be different. Since the signal arising from stimulation of a facet joint must travel along each of its two medial branches, pass through their respective dorsal root ganglia, and travel to their respective receptive fields on the dorsa horn via the second order neuron, it seems reasonable that the receptive field for the facet joint should be larger than that of the medial branch alone. Indeed, we found the area of perceived stimulation of the medial branch and third occipital nerve to be substantially smaller than that induced by stimulation of the facet joint. Under unusual circumstances of chronic or severe pain, patients may experience "wind up" thus causing the region of referred pain to be enlarged when compared to normal subjects (117). This phenomenon must be taken into account when considering this data during the treatment of pain patients.

\section{CONCLUSION}

All 64 referral patterns were meticulously mapped and well controlled. All of the subjects' referral patterns agreed well with one another except for some minor variation in orientation. In general, all referral patterns were isolated to a small region lateral to the point of stimulation.
Orientation of the referral pattern varied slightly in $40 \%$ of subjects in the lower cervical spine but not enough to discount injury or irritation of the medial branch as a possible etiology of a focal cervical pain syndrome.

These referral maps differ from those reported for the cervical facet joints and may have different clinical implications. These referral maps may provide the clinician with additional insight when evaluating a patient with suboccipital, cervical, or shoulder girdle pain.

\section{Author Affiliation \\ Robert E. Windsor, MD}

Program Director \& President

Georgia Pain Physicians

Emory University

2550 Windy Hill Road, Suite 215

Atlanta, GA 30067

E-mail: rwindsor@aol.com

\section{Diwakar Nagula, DO}

Faculty

Georgia Pain Physicians

Emory University

2550 Windy Hill Road, Suite 215

Atlanta, GA 30067

Seneca Storm, MD

Fellow

Georgia Pain Physicians

Emory University

2550 Windy Hill Road, Suite 215

Atlanta, GA 30067

E-mail: Senecastorm@hotmail.com

\section{Anthony Overton, DO}

Fellow

Georgia Pain Physicians

Emory University

2550 Windy Hill Road, Suite 215

Atlanta, GA 30067

\section{Scott Jahnke, DO}

Fellow

Georgia Pain Physicians

Emory University

2550 Windy Hill Road, Suite 215

Atlanta, GA 30067

\section{References}

1. Barnsley L, Bogduk N. Medial branch blocks are specific for the diagnosis of cervical zygapophyseal joint pain. Reg Anesth 1993; 18:343-350.

2. Jull G, Bogduk N, Marsland A. The accuracy of manual diagnosis for cervical zygapophysial joint pain syndromes. Med I Aust 1988; 48:233-236.

3. Lewis T. Observations of pain provocation in 
various tissues. Brit Med J 1938; 1:321-327.

4. Kellgren J. Observations of pain arising from muscle. Clin Sci 1938; 3:175-190.

5. Lewis T. Kellgren J. Observations relating to referred pain, visceromotor reflexes and other associated phenomena. Clin Sci 1939; 1:47-71.

6. Cloward R. Cervical discography. A contribution of the etiology of neck, shoulder, and arm pain. Ann Surg 1959; 150:1052-1064.

7. Goldthwait J. The lumbosacral articulation: An explanation of many cases of "lumbago, sciatica, and paraplegia." Boston Med Surg 1911; 164:356-372.

8. Ghormley R. Low back pain with special reference to the articular facets, with presentation of an operative procedure. JAMA 1933; 101:1773-1777.

9. Mooney V, Robertson J. The facet syndrome. Clin Orthop 1976; 115:149-156.

10. McCall IW, Park WM, O’Brien JP. Induced pain referral from posterior lumbar elements in normal subjects. Spine 1979; 4: 441-446.

11. Kaplan M, Dreyfuss P, Halbrook B et al. The ability of lumbar medial branch blocks to anesthetize the zygapophyseal joint a physiologic challenge. Spine 1997; 22: 895-902.

12. Schwarzer AC, April CN, Derby $\mathrm{R}$ et al. Clinical features of patients with pain stemming from the lumbar zygapophyseal joints: Is the lumbar facet syndrome a clinical entity? Spine 1994; 19:1132-1137.

13. Bogduk N. International Spine Injection Society guidelines for the performance of spinal injection procedures. Part 1: Zygapophyseal joint blocks. Clin J Pain 1997; 13:285-302.

14. Schwarzer AC, Wang S, Bogduk N et al. Prevalence and clinical features of lumbar zygapophyseal joint pain: A study in an Australian population with chronic low back pain. Ann Rheum Dis 1995; 54:100-106.

15. Schwarzer AC, Aprill CN, Derby R et al. The relative contributions of the disc and zygapophyseal joint in chronic low back pain. Spine 1994; 19:801-806.

16. Manchikanti L, Pampati VS, Fellows B et al. Prevalence of lumbar facet joint pain in chronic low back pain. Pain Physician 1999; 2:59-64.

17. Manchikanti L, Singh V, Pampati VS et al. Evaluation of the relative contributions of various structures in chronic low back pain. Pain Physician 2001; 4:308-316.

18. Manchikanti L, Pampati VS, Fellows B et al. The diagnostic validity and therapeutic value of medial branch blocks with or without adjuvants. Curr Rev Pain 2000; 4:337-344.

19. Berven S, Tay B, Colman W et al. The lum bar zygapophyseal (facet) joints: A role in the pathogenesis of spinal pain syndromes and degenerative spondylolisthesis. Semin Neurol 2002; 22:187-196.

20. Dreyfuss P, Dreyer S, Herring S. Lumbar zygapophysial (facet) joint injections. Spine 1995; 20:2040-2047.
21. Manchikanti L. Facet joint pain and the role of neural blockade in its management. Curr Rev Pain 1999; 3:348-358.

22. Jackson R, Jacobs R, Montesano P. 1988 Volvo award in clinical sciences. Facet joint injection in low-back pain. A prospective statistical study. Spine 1988; 13:966-971.

23. Windsor R. Radiofrequency lumbar zygapophysial (facet) joint denervation: A preliminary report of a new concept. Pain Physician 2003; 6:119-123.

24. Windsor R, King F, Roman S et al. Electrical stimulation induced lumbar medial branch referral patterns. Pain Physician 2002; 5: 347-357.

25. Desoutet J, Gilula L, Murphy W et al. Lumbar facet joint injection: Indication, technique, clinical correlation and preliminary results. Radiology 1982; 145:321-325.

26. Dreyfuss P, Halbrook B, Pauza K et al. Efficacy and validity of radiofrequency neurotomy for chronic lumbar zygapophysial joint pain. Spine 2000; 25:1270-1277.

27. van Kleef M, Barendse G, Kessels A et al. Randomized trial of radiofrequency lumbar facet denervation for chronic low back pain. Spine 1999; 24:1937-1949.

28. Schwarzer AC, Wang S, Laurent R et al. The role of the zygapophysial joint in chronic low back pain. Aust NZJ Med 1992; 22:185.

29. Schwarzer AC, Wang S, O'Driscoll D et al. The ability of computed tomography to identify a painful zygapophysial joint in patients with chronic low back pain. Spine 1995; 20:907-912.

30. Dreyfuss P. Schwarzer AC, Lau P et al. The target specificity of lumbar medial branch and $\mathrm{L}_{5}$ dorsal ramus blocks. A computed tomography study. Spine 1997; 22:895-902.

31. Bradley KC. The anatomy of backache. Aust N Z J Surg 1974; 44:227-232.

32. Dory MA. Arthrography of the lumbar facet joints. Radiology 1981; 140:23-27.

33. Dreyer S, Dreyfuss P. Low back pain and the zygapophysial (facet) joints. Arch Phys Med Rehabil 1996; 77:290-300.

34. Dreyfuss P, Dreyer S. Contemporary concepts in spine care: Lumbar zygapophysial (facet) joint injections. Spine 1995; 20: 2040-2047.

35. Emminger E. Les articulations interapophysaires et leurs structures meniscoides vue sous l'angle de la pathologie. Annales de Medecine Physique 1972; 15:219-238.

36. Fairbank JCT, Park WM, McCall IW et al. Apophyseal injection of local anesthetic as a diagnostic aid in primary low back pain syndromes. Spine 1981; 6:598-605.

37. Fassio B, Bouvier JP, Ginestie JF. Denervation articulaire posterieure per-cutanee et chirurgicale. Sa place dans le traitement des lombalgies. Rev Chir Orthop 1980; 67: S131-S136.

38. Moran R, O'Connell D, Walsh M. The diagnostic value of facet joint injections. Spine 1988; 13:1407-1410.

39. Silver R. Lumbar percutaneous facet rhizotomy. Spine 1990; 15:36-40.
40. Shealy C. Facet denervation in the management of back and sciatic pain. Clin Orthop 1976; 115:157-164.

41. Shealy C. Percutaneous facet rhizotomy in the treatment of chronic back and neck pain. Int Surg 1975; 43:448-451.

42. Eisenstein S, Parry C. The lumbar arthrosis syndrome. J Bone Joint Surg 1987; 69B:3-7.

43. Ayers C. Further case studies of lumbosacral pathology with consideration of involvement of the intervertebral discs and articular facets. N Engl J Med 1935; 213: 716-721.

44. Badgley C. The articular facets in relation to low back pain and sciatic radiation. I Bone Joint Surg 1941; 23:481-596.

45. Carrera G, Williams A. Current concepts in evaluation of the lumbar facet joints. Crit Rev Diagn Imaging 1984; 21:85-104.

46. Carrera G. Lumbar facet joint injection in low back pain and sciatica: Preliminary results. Radiology 1980; 137:665-667.

47. Carrera G. Lumbar facet joint injection in low back pain and sciatica: Description of technique. Radiology 1980; 137:661-664.

48. Carrera G. Lumbar facet arthrography and injection in low back pain. Wis Med J 1979; 78:35-37.

49. Dunlop R, Adams M, Hutton W. Disc space narrowing and the lumbar facet joints. J Bone Joint Surg [Br] 1984; 66B:706-710.

50. Oppenheimer A. Diseases of the apophyseal (intervertebral) articulations. J Bone Joint Surg 1938; 20:285-313.

51. Yang K, King A. Mechanism of facet load transmission as a hypothesis for low-back pain. Spine 1984; 9:557-565.

52. Adams M, Hutton W. The mechanical function of the lumbar apophyseal joint. Spine 1983; 8:327-330.

53. Ashton I, Cavanugh J, Ozaktay C et al. The effects of controlled mechanical loading on type II, III, and IV afferent units from the lumbar facet joints and surrounding tissues. An in vitro study. J Bone Joint Surg 1992; 74:72-78.

54. Ayers C. Lumbo-sacral backache. New Engl J Med 1929; 200:592-608.

55. Helbig T, Lee $C$. The lumbar facet syndrome. Spine 1988; 13:61-64.

56. Hirsch D, Ingelmark B, Miller M. The anatomical basis for low back pain. Acta Orthop Scandinav 1963; 33:1-7.

57. Jackson R, Jacobs R, Montesano P. Facet joint injections in low back pain: A prospective study. Spine 1988; 13:966-971.

58. Lau L, Littlejohn G, Miller M. Clinical evaluation of intra-articular injections for lumbar facet joint pain. Med J Aust 1985; 143: 563-565.

59. Lewin T, Moffet B, Viidik A. The morphology of the lumbar synovial intervertebral joints. Acta Morphol Neerlando-Scandinav 1962; 4:299-319.

6o. Lewinnek G, Warfield C. Facet joint degeneration as a cause of low back pain. Clin 
Orthop 1986; 213:216-222.

61. Lilius G, Laasonen E, Myllynen P et al. Lumbar facet joint syndrome: A randomized clinical trial. J Bone Joint Surg 1989; 71B:681-684.

62. Lippit A. The facet joint and its role in spine pain: management with facet joint injections. Spine 1984; 9:746-750.

63. Lynch M, Taylor J. Facet joint injections for low back pain. J Bone Joint Surg 1986; 68B:138-141.

64. Maldague B, Mathurin P, Malghem J. Facet joint arthrography in lumbar spondylosis. Radiology 1981; 140:29-36.

65. Marks R. Distribution of pain provoked from lumbar facet joints and related structures during diagnostic spinal infiltration. Pain 1989; 39:37-40.

66. Manchikanti L, Staats P, Singh V et al. Evidence-based practice guidelines for interventional techniques in the management of chronic spinal pain. Pain Physician 2003; 6:3-80.

67. Murtagh F. Computed tomography and fluoroscopy guided anaesthesia and steroid injection in facet syndrome. Spine 1988; 13:686-689.

68. Park W, McCall I, Benson D et al. Spondyloarthropathy: The demonstration of spondylosis by apophyseal joint arthrography. Clin Radiol 1985; 36:427-430.

69. Putti V. New conceptions in the pathogenesis of sciatic pain. Lancet 1927; 2:53-60.

70. Raymond J, Dumas J. Intra-articular facet block: Diagnostic tests or therapeutic procedure? Radiology 1984; 151:333-336.

71. Revel M, Listrat V, Chevalier X et al. Facet joint block for low back pain: Identifying predictors for good response. Arch Phys Med Rehabil 1992; 73:824-828.

72. Selby D, Paris S. Anatomy of facet joints and its correlation with low back pain. Contemp Orthop 1981; 312:1097-1103.

73. Jackson R. The facet syndrome. Myth or reality? Clin Orthop 1992; 279:110-121.

74. Lord S, B, Barnsley L, Wallis B et al. Percutaneous radio-frequency neurotomy for chronic cervical zygapophyseal joint pain. New Engl J Med 1996; 335:1721-1726.

75. Dwyer A, Aprill C, Bogduk, N. Cervical zygapophyseal joint pain patterns I: A study in normal volunteers. Spine 1990; 6:453-457.

76. Aprill C, Dwyer A, Bogduk N. Cervical zygapophyseal joint pain patterns. II: A clinical evaluation. Spine 1990; 15:458-461.

77. Bogduk N. The clinical anatomy of the cervical dorsal rami. Spine 1982; 7:319-330.

78. Bogduk N. Neck Pain. Aust Fam Phys 1984; 13:26-30.

79. Bogduk N, Marsland A. The cervical zygapophyseal joints as a source of neck pain. Spine 1988; 13:610-617.

80. Dory MA. Arthrography of the cervical facet joints. Radiology 1983; 148:379-382.

81. Dussault RG, Nicolet VM. Cervical facet joint arthrography. J Can Assoc Radiol $1985 ; 36: 79-80$.
82. Chevrot A, Cermakova E, Vallee C. $\mathrm{C}_{1} / \mathrm{C}_{2}$ arthrography. Skeletal Radiol 1995; 24: 425-429.

83. Dreyfuss P, Rogers J, Dreyer $\mathrm{S}$ et al. Atlanto-occipital joint pain. Reg Anaesth 1994; 19:344-345.

84. Hove B, Gyldensted C. Cervical analgesic facet joint arthrography. Neuroradiology 1990; 32:456-459.

85. Roy DF, Fleury J, Fontaine SB et al. Clinical evaluation of cervical facet joint infiltration. J Can Assoc Radiol 1988; 39:118-120.

86. Wedel D, Wilson P. Cervical facet arthrography. Reg Anaesth 1985; 10:7-11.

87. Slipman C, Lipitz J, Plastaras C et al. Therapeutic zygapophyseal joint injections for headaches emanating from the $\mathrm{C}_{2}-3$ joint. Am J Phys Med Rehabil 2001; 80:182-185.

88. Dreyfuss, P, Michaelsen M, Fletcher D. Atlanto-occipital and lateral atalanto-axial joint pain patterns. Spine 1994; 19:1125-1131.

89. Barnsley L, Lord S, Wallis B et al. The prevalence of chronic cervical zygapophysial joint pain after whiplash. Spine 1995; 20:20-25.

90. Lord S, Barnsley L, Wallis B et al. Chronic cervical zygapophysial joint pain after whiplash. A placebo-controlled prevalence study. Spine 1996; 21:1737-1744.

91. Manchikanti L, Singh V, Rivera J et al. Prevalence of cervical facet joint pain in chronic neck pain. Pain Physician 2002; 5:243-249.

92. Manchikanti L, Singh V, Pampati V et al. Is there correlation of facet joint pain in lumbar and cervical spine? An evaluation of prevalence in combined chronic low back and neck pain. Pain Physician 2002; 5:365-371.

93. Speldewinde G, Bashford G, Davidson I. Diagnostic cervical zygapophyseal joint blocks for chronic cervical pain. Med J Aust 2001; 174:174-176.

94. Maigne JY. Chronic cervical zygapophysial joint pain after whiplash--A placebocontrolled prevalence study. Spine 1997; 22:1420-1421.

95. Kopp S, Plato G, Bumann A. Significance of the upper neck joints in the etiology of pain in the head and neck area. Dtsch Zahnarztl Z 1989; 44:966-967.

96. Fukui S, Ohseto K, Shiotani M et al. Referred pain distribution of the cervical zygapophyseal joints and cervical dorsal rami. Pain 1996; 68:79-83.

97. Aprill C, Axinn M, Bogduk N. Occipital headaches stemming from the lateral atlanto-axial (C1-2) joint. Cephalalgia 2002; 22:15-22.

98. Bogduk N, Aprill C. On the nature of neck pain, discography and cervical zygapophysial joint blocks. Pain 1993; 54:213-217.

99. Aprill C, Bogduk N: The prevalence of cervical zygapophyseal joint pain. A first approximation. Spine 1992; 17:744-774.

100. Barnsley L, Lord S, Wallis B et al. Lack of effect of intraarticular corticosteroids for chronic pain in the cervical zygapophyseal joints. N Engl J Med 1994; 330:1047-1050.

101. McDonald G, Lord S, Bogduk N. Long-term follow-up of patients treated with cervical radiofrequency neurotomy for chronic neck pain. Neurosurgery 1999; 45:61-67.

102. Sapir D, Gorup J. Radiofrequency medial branch neurotomy in litigant and non-litigant patients with cervical whiplash: A prospective study. Spine 2001; 26:E268-E273.

103. Wallis B, Lord S, Bogduk N. Resolution of psychological distress of whiplash patients following treatment by radiofrequency neurotomy: A randomised, double-blind, placebo-controlled trial. Pain 1997; 73:15-22.

104. Fishbain D. Resolution of psychological distress of whiplash patients following treatment by radiofrequency neurotomy: A randomized, double-blind, placebo-controlled trial. Pain 2000; 84:113-114.

105. Kwan O, Fiel J. Critical appraisal of facet joints injections for chronic whiplash. Med Sci Monit 2002; 8:RA191-RA195.

106. Geurts J, van Wijk R, Stolker R et al. Efficacy of radiofrequency procedures for the treatment of spinal pain: a systematic review of randomized clinical trials. $R e g$ Anesth Pain Med 2001; 26:394-400.

107. Niemisto L, Kalso E, Malmivaara A et al. Radiofrequency denervation for neck and back pain. A systematic review of randomized controlled trials. Cochrane Database Syst Rev 2003; 1:CDo04058.

108. Niemisto L, Kalso E, Malmivaara A et al. Radiofrequency denervation for neck and back pain: a systematic review within the framework of the Cochrane collaboration back review group. Spine 2003; 28:1877-1888.

109. Schaerer J. Radiofrequency facet denervation in the treatment of persistent headache associated with chronic neck pain. J Neurol Orthop Surg 1980; 1:127-130.

110. Schaerer J. Radiofrequency facet rhizotomy in the treatment of chronic neck and back pain. Int Surg 1978; 63:53-59.

111. Bogduk N, Marsland A. On the concept of third occipital headache. J Neurol Neurosurg Psychiatry 1986; 49:775-780.

112. Govind J, King W, Bailey B et al. Radiofrequency neurotomy for the treatment of third occipital headache. J Neurol Neurosurg Psychiatry 2003; 74:88-93.

113. Bogduk N. The anatomic basis for cervicogenic headaches. J Manipulative Physiol Ther 1992; 15:67-70.

114. Fisher M, Kaur D, Houchins J. Electrodiagnostic examination, back pain, and entrapment of posterior primary rami. Electromyogr Clin Neurophysiol 1985; 25:183-189.

115. Sihvonen T, Lindgren K, Airaksinen $\mathrm{O}$ et al. Dorsal ramus irritation associated with recurrent low back pain and its relief with local anesthetic or training therapy. J Spinal Disord 1995; 8:8-14.

116. Bastron J, Thomas JE. Diabetic polyradic ulopathy: Clinical and electromyographic findings in 105 patients. Mayo Clin Proc 1981; 56:725-732.

117. Hanai F. C fiber responses of wide dynamic range neurons in the spinal dorsal horn. Clin Orthop 1998; 349:256-257. 